\title{
İntihar Saldırıları Üzerine Bir İnceleme: Çeçen İntihar Eylemleri
}

\author{
An Analysis of Suicide Attacks: \\ Chechen Suicide Actions
}

\author{
Halit GÜLŞEN*
}

\begin{abstract}
Öz
İtihar saldırılarl, savaş ve çatışma bölgeleri başta olmak üzere dünya genelinde yaygin olarak kullanılan bir terör yöntemi haline gelmiştir. Bu yöntemin kullanıldı̆̆ bölgelerden biri de uzun yillardır Rusya Federasyonu (RF) olmuştur. Bu çalışmanın amact, intihar saldirllarl ve Çeçen intihar eylemcileri konusunda Türkçe akademik yazınına katkıda bulunmaktır; çünkü yapılan araştırmada intihar saldırıları konusunda Türkçe kaynakların çok sinırlı olduğu, Çeçenler tarafindan RF'de düzenlenen intihar eylemleri konusunda ise Türkçe bilimsel çalışma bulunmadı̆̆ görülmü̈şür. Bu nedenlerden dolayı çalışmanın Türkçe literatüre önemli katkısı olacaktır. Çalışmada "insanlar neden canlı bomba olur" sorusu, ana araşttrma sorusudur. Ardından Çeçenlerin Rusya'da düzenledikleri canlı bomba eylemleri incelenecek ve Çeçenleri canlı bomba olmaya iten nedenler ve koşullar açıklanacaktır. Bu çerçevede, literatürde yer alan kavramların, Çeçen vakast ile hangi noktalarda örtüşüp hangi noktalarda ayrıştı̆g tespit edilecektir.
\end{abstract}

Anahtar Kelimeler: Intihar saldırısı, Çeçen, Radikalleşme, Rusya, Çeçenistan.

Doktora Öğrencisi, Ankara Sosyal Bilimler Üniversitesi, Ortadoğu Çalışmaları Programı, e-posta: gulsenhalit@gmail.com.

Geliş Tarihi / Arrived: 21.03.2018

Kabul Tarihi / Accepted: 18.02.2019 


\section{Halit GÜLŞEN}

354

Güvenlik

Stratejileri

Cilt: 15

Sayı: 30

Abstract

Suicide attacks are widely applied terror method all around the world primarily in the war and conflict zones. Russian Federation, where Chechen Independence Struggle happens for years, is one of the countries in which this method is applied. This study aims to contribute to Turkish literature with regard to suicide attacks and Chechen suicide bombers. In previous studies, it is understood that there is limited Turkish research on suicide attacks. Furthermore, there has been no academic research in Turkish about suicide bomb attacks erupting in Russia conducted by Chechens. For these reasons, this research will contribute to Turkish literature. "Why people become suicide bomber" is the central question in this research. Then, the suicide attacks perpetrated by Chechens and the factors behind it will causally be examined and explained. Therefore, how the concepts in the literature overlap and diverge from the Chechen case in the conceptual framework will be surfaced.

Keywords: Suicide attack, Chechen, Radicalization, Russia, Chechenia.

\section{Giriș}

İntihar saldırıları, diğer bir ifadeyle canlı bomba eylemleri, ${ }^{1}$ hem ulusal, hem de uluslararası güvenlik açısından büyük önem arz etmektedir. Özellikle Soğuk Savaş'ın sona ermesinin ardından savaşların giderek devletlerarası olmaktan çıkarak iç savaş şeklini alması ile birlikte, terör örgütleri başta olmak üzere çok sayıda devlet dışı aktör görünür olmaya başlamıştır. Bu dönemle birlikte "eski savaş" ve "modern savaş" terimleri yerini "yeni savaş" ifadesine bırakmıştır. ${ }^{2}$ Ya da "birinci nesil", "ikinci nesil" ve "üçüncü nesil savaşlar"1n yerine artık "dördüncü nesil savaşlar"

${ }^{1}$ Makalenin devamında bir ikiliğge yol açmamak için sadece "intihar saldırısı" ifadesi kullanılacaktır.

${ }^{2}$ Mary Kaldor, "In Defence of New Wars", Stability, 2013, Sayı 4, s. 6.; Ali L. Karaosmanoğlu, "Yirmibirinci Yüzyılda Savaşı Tartışmak: Clausewitz Yeniden", Uluslararası İlişkiler, 2011, Cilt 8, Sayı 29, s. 6. 
İntihar Saldırıları Üzerine Bir İnceleme: Çeçen İntihar Eylemleri

tanımlaması yapılmaktadır. ${ }^{3}$ Gerek “yeni nesil”, gerekse “dördüncü nesil savaşlarda" en önemli faktörlerden birisi olan terör örgütlerinin yaklaşık son on beş yılda ağırlık verdiği saldırı yöntemlerinden biri ve belki de en etkilisi intihar saldırılarıdır. Söz konusu yönteminin 2000'li yıllardan itibaren Rusya topraklarında bağımsızlık yanlısı Çeçen silahlı gruplar tarafindan da artan şekilde kullanıldığı karşımıza çıkmaktadır. Çeçenlerin sadece Rusya topraklarında değil, dünyanın farklı bölgelerinde devam eden savaşlarda da gönüllü olarak aktif bir şekilde yer alması Çeçenlerin intihar saldırısı yöntemini kullanmasını daha da önemli bir hüviyete büründürmektedir. ${ }^{4} \mathrm{Bu}$ nedenlerle üzerinde çalıştığımız konu ulusal ve uluslararası güvenlik çalışmaları açısından önem taşımaktadır.

$\mathrm{Bu}$ noktadan hareketle, makalede ilk olarak intihar saldırılarının literatürdeki yeri üzerinde durulacaktır. Literatüre baktığımızda, insanları intihar eylemcisi olmaya iten birçok neden bulunmaktadır ve tek bir intihar eylemcisi profili yoktur. Eylem ve eylemciler kişisel yaşanmışlıklara ve coğrafyaya göre farklılık göstermektedir. Ancak genel olarak baktığımızda intihar eylemlerinin radikalleşme, kimlik sorunu, psikolojik faktörler, sosyolojik nedenler, maddi unsurlar, rasyonel gerekçeler ya da milliyetçilik gibi farklı nedenlerinin bulunduğu görülmektedir. Biz ise çalışmamızda ağırlıklı olarak radikalleşme olgusunun üzerinde duracak ve insanların nasıl radikalleşerek sadece kendi hayatına değil, hiç tanımadıkları onlarca insanın da hayatına son verme noktasına gelebildiklerini inceleyerek, insanların neden intihar eylemcisi olduğu sorusuna cevap bulmaya çalışacağız. Makalenin ikinci bölümünde ise bir vaka çalışması olarak Çeçen intihar eylemleri ele alınacaktır. Bu bölümde Rusya toprakları içinde ${ }^{5}$ bağımsızlık

\footnotetext{
${ }^{3}$ William Lind, Keith Nightengale, John Schmitt, Joseph Sutton, Gary Wilson, "The Changing Face of War: Into the Fourth Generation", Marine Corps Gazette, 1989, s. 26.

${ }^{4}$ Afganistan, Irak, Gürcistan, Ukrayna ve son olarak da Suriye'de meydana gelen ve hâlâ devam eden savaşlarda, önemli derecede Çeçen yabancı savaşçı yer almaktadır.

$5 \mathrm{Bu}$ çalışmada Çeçenlerin sadece Rusya toprakları içinde yaptıkları intihar eylemlerinin nedenleri incelenecektir. Çeçen savaşçılar gönüllü savaşçı olarak gittikleri farklı ülkelerde bulundukları intihar eylemleri çalışmanın kapsamına girmemektedir.
}

\section{5}

Güvenlik Stratejileri

Cilt: 15

Sayı: 30 
yanlısı Çeçen silahlı grupları intihar saldırısı eyleminde bulunmaya iten nedenler belirtilecektir. Bu kapsamda Birinci Çeçen Savaşı ve İkinci Çeçen Savaşı'nın ardından ülkelerinden göç ederek Türkiye'ye yerleşen ve hâlen Türkiye' de bulunan 15 Çeçen ile yapılan mülakatlara yer verilecektir. Mülakatlarda elde edilen veriler mevcut literatürde intihar eylemcisi olmaya iten gerekçelerle karşılaştırılacaktır. Böylece Çeçen intihar eylemlerinin literatürle ayrışıp ayrışmadığ 1 test edilmiş olacaktır. Mülakatların verilerinde güvenlik gerekçesi ile gerçek isimler kullanılmayacak ancak mülakat yapılan kişilerin yaşlarına dair bilgi verilecektir. İsim yerine "örnek 1", “örnek 2" şeklinde model kullanılacaktır. Üçüncü bölümde ise mülakat yöntemiyle elde edilen verilerin literatürdeki genel intihar eylemlerinin nedenleri ile hangi noktalarda örtüştüğü, hangi noktalarda ayrıldığının analizi yapılmaya çalışılacaktır. Son bölümde ise Çeçen intihar eylemlerine dair ulaşılan temel bulgular üzerinde durularak genel bir değerlendirme yapılacaktır.

\section{1. İntihar Saldırılarının Literatürdeki Yeri}

Literatürde intihar saldırılarının nedenleri arasında radikalleşme, milliyetçilik, psikolojik ve toplumsal nedenler, maddi nedenler, rasyonalite, halk desteği, intikam duygusu gibi argümanların öne çıktığı görülmektedir.

Kushner, çalışmalarında intihar saldırısı eylemleri ile dinî fanatizmin kesiştiğini belirmektedir. ${ }^{6}$ Bu noktada birçok çalışmadan yararlanan ve eserlerinde geniş bir literatüre yer veren yazarlar, intihar eylemlerinde dinî fanatizm ve radikalizm etkinliğinin ağırlıklı olduğunu savunmaktadır. Aydınalp, Müslüman kimliği taşıyan eylemcilerin gerçekleştirdikleri intihar eylemlerinin dinî bir mana evreni içinde nasıl meşrulaştırıldığı ve bu dinî meşruiyet kurgusunun anlamı ve sınırlarını ele almıştır. ${ }^{7} \mathrm{Bu}$ kapsamda, dinin çatışma sürecinin neresinde yer aldığı,

\footnotetext{
${ }^{6}$ Harvey W. Kushner, "Suicide Bombers: Business as Usual", Studies in Conflict and Terrorism, 1996, Cilt 4, s. 329-337.

${ }^{7}$ Halil Aydınalp, İntihar Eylemleri Ekseninde Din ve Terör İlişkisi, Doktora Tezi, Marmara Üniversitesi İlahiyat Fakültesi Sosyal Bilimler Enstitüsü, İstanbul, 2008, s. 184.
} 
İntihar Saldırıları Üzerine Bir İnceleme: Çeçen İntihar Eylemleri

dinî radikalizm içinde dinî idealizmin yeri, eylemlerin İslam meşruiyeti sorunu, eylemlerde dinî motivasyon ve meşrulaştırma problemlerine değinmiş ve dinin yanlış yorumlanmasının dinî fanatizmi beraberinde getirdiğini belirtmiştir. Aynı noktada, Akdaş ise, intihar saldırılarının, sosyolojik nedenleri yanında dinî ve ideolojik temelinin olup olmadığını sorgulamış ve bu hususların intihar saldırılarında ne kadar etkili olduğunu araştırmış ve etkili olduğu sonucuna varmıştır. ${ }^{8}$

Sprinzak, konuyu rasyonel teori çerçevesinde incelemiştir. İntihar saldırılarında taktiksel ve stratejik açıdan bir mantık olduğunu belirterek, eylemcilerin rasyonel aktörler olduğunu dile getirmiştir. ${ }^{9}$ Benzer biçimde, Atran da intihar saldırısı eylemlerinin hedefe yönelik gücünden, saldırı esnasında operasyonel ayarlama yapılabilmesinden, çok yönlü bir eylem olması açısından eylemcilerin rasyonel bir çerçevede bu yöntemi kullandıklarını kaydetmektedir. ${ }^{10}$ Bloom, intihar saldırılarının etkinliğine yönelik Filistin örneğinden hareket ederek intihar eylemlerine verilen halk desteği üzerinde durmuş ve sosyolojik yapıya değinmiştir. ${ }^{11}$ Ayrıca yaptığı saha çalışmalarında intihar eylemi türünün sanılanın aksine bir terör örgütünün güçsüzlüğünü ya da paniğe kapıldığını değil, tersine güçlü ve serinkanlı bir tarzda hareket ettiğini gösterdiğini kaydetmiştir. ${ }^{12}$

Bu noktada, Aydınalp da, Türkiye'de terör örgütleri tarafından gerçekleştirilen intihar saldırılarını sosyolojik ve psikolojik yönden incelenmiş ve önlenebilmesi için alınması gerekenleri ortaya koymuştur. ${ }^{13}$ Araştırmasında istatistikî verilerden elde edilen bulguların sonucunda intihar eylemcilerinin büyük çoğunluğunun alt ekonomik kategoride

\footnotetext{
${ }^{8}$ Fatih Akdaş, İntihar Terörizm ve Din, Yüksek Lisans Tezi, Kahramanmaraş Sütçü İmam Üniversitesi Sosyal Bilimler Enstitüsü, Kahramanmaraş, 2009, s. 25.

${ }^{9}$ Ehud Sprinzak, "Rational Fanatics", Foreign Policy, 2000, Say1 120, s. 69.

${ }^{10}$ Scott Atran, "Genesis of Suicide Terrorism", 2003, Science, Say1 299, s. 1536.

${ }^{11}$ Türkiye ve Terörizm, Türkiye Barolar Birliği, Türkiye Barolar Birliği Yayınları, 2006, s. 189.; Mia Bloom, Dying to Kill: The Allure of Suicide Terror, Columbia University Press, New York, 2005, s. 21.

12. Bloom, a.g.e., s. 22.

${ }^{13}$ Halil Aydınalp, "İntihar Eylemlerinde Dinin Anlamı ve Sınırları", M. ̈̈. İlahiyat Fakültesi Dergisi, 2009, Sayı 37, s. 136.
}

\section{7}

Güvenlik Stratejileri

Cilt: 15

Sayı: 30 


\section{Halit GÜLŞEN}

358

Güvenlik Stratejileri

Cilt: 15

Sayı: 30

yer alan çok çocuklu ailelerin mensubu ve eğitim düzeylerinin düşük olduğunu, daha çok 20'li yaşlarda olduklarını, işsiz ve öğrenci olanların ilk sıralarda yer aldığını, daha çok Doğu Anadolu ve Güneydoğu Anadolu Bölgeleri'nden geldiklerini belirtmiştir. Sevinç ${ }^{14}$ ise, intihar bombacılarının demografik özelliklerini incelenmiş ve sonu ölüm olmasına rağmen intihar bombacılarının bunu nasıl rasyonelize ettikleri ve hangi faktörlerin intihar bombacılarını motive ettiği sorularına yanıt aramıştır. Burada da rasyonalitenin ön plana çıktığı görülmüştür.

İntihar saldırılarının altında yatan nedenlerden biri olarak psikolojik faktörleri gösteren Sarraj, ailesinin ya da sevdiklerinden birinin gözünün önünde şiddete maruz kaldığını gören gençlerin, ileriki dönemde daha fazla şiddete eğilim gösteren bir ruhaniyete büründüğünü kaydetmiştir. ${ }^{15}$ Şiddet görmenin ileri dönemlerde şiddet göstermek için bir motivasyona neden olduğunu belirtmiştir. Açıkgöz de bir öldürme eylemi ve intikam aracı olarak ele alınan intihar saldırılarının belirli coğrafyalarda, özellikle şiddetli çatışma ve işgallerin yaşandığı yerlerde, yoğunlaştığına dikkat çekmektedir. ${ }^{16}$ Burada Sarraj ile aynı noktada buluşan Açıkgöz, ayrıca intihar saldırılarını terör ve özgürlük arayışı bağlamında incelemektedir. Mühürcüoğlu da intihar saldırılarının psikolojik etkisi üzerinde durarak, Ulus-Anafartalar Çarşısı esnafinın 2007'de yaşamış oldukları bombalı intihar saldırısının korkularını ne kadar etkilediğine yönelik bir saha çalışması ortaya koymuştur. ${ }^{17}$

Kimlik konusu da intihar saldırılarında önemli bir yer edinmektedir. $\mathrm{Bu}$ noktada Volkan, büyük grup kimliğinin birey hayatında oynadığı

${ }^{14}$ Bilal Sevinç, "İntihar Bombacıları ve Ölümün Rasyonelleştirilmesi”, Uluslararası Güvenlik ve Terörizm Dergisi, 2012, Sayı 3(1), s. 76.

${ }^{15}$ Eyad El Sarraj and Linda Butler, "Suicide Bombers: Dignity, Despair, and the Need for Hope: An Interview with Eyad El Sarraj," Journal of Palestine Studies, 2002, Sayı 31, no. 4, s. 74.

${ }^{16}$ Reşat Açıkgöz, “İntihar Saldırıları: Terör mü Özgürlük Arayışı mı?”, Akademik Incelemeler Dergisi, 2013, Cilt 8, Sayı 2, s. 303.

${ }^{17}$ Evren Mühürcüoğlu, Bombalı İntihar Saldırısı Sonucu Oluşan Suç Korkusu Üzerine Bir Vaka İncelemesi: Ulus-Anafartalar Çarşısı Örneği, Yüksek Lisans Tezi, Hacettepe Üniversitesi Sosyal Bilimler Enstitüsü, 2010, s. 5. 
İntihar Saldırıları Üzerine Bir İnceleme: Çeçen İntihar Eylemleri

belirleyici rolü intihar bombacısı Filistinli çocuklar örneğinden yola çıkarak açıklamaktadır. ${ }^{18}$ Bireylerin aidiyetlerini grup kimliği ile bütünleştirerek kendilerini o grup ile ifade edebildiklerini söyleyen Volkan, böylece ait olduğu grubun devamlılığını sağlamak isteyen bireyin kendi kimliğinden vazgeçerek grup ile özdeşim yaptığını vurgulamaktadır.

İntihar bombacılarının bütün dünyada geçerli olan tek bir kişilik profilinin olmadığını belirten Yahşi; bölgelere, toplumun ve terör örgütünün yapısına göre intihar saldırılarının özelliklerinin değiştiğini kaydetmektedir. ${ }^{19}$

İntihar saldırıları bağlamında Rusya'da Çeçenler tarafindan düzenlenen saldırılara bakıldığında ise, literatürde ilk göze çarpan kadın Çeçen intihar eylemciler üzerine yapılan çalışmalardır. Spechard ve Ahmedova Çeçen kadın canlı bombaları inceledikleri saha çalışmasında, hepsinin intihar eylemi öncesinde cihadist bir eğitim aldıklarını kaydederek, milliyetçiliğin ve psikolojik etkilerin de Çeçen kadın intihar eylemcileri üzerinde etki eden önemli faktörler olduğu tespitinde bulunmaktadır. ${ }^{20}$ Banner, Rus-Çeçen çatışmasında kadınların rolünü incelerken, Çeçen kadınların milliyetçilik duygusuna, savaşta eşlerini kaybetmekten dolayı intikam alma hırslarına ve dinî duygulara referans vermektedir. ${ }^{21} \mathrm{Bu}$ noktada Koyuncu ise konuya tamamen farklı bir açıdan yaklaşmaktadır. Feminist uluslararası teori açısından Çeçen kadın intihar eylemcilerini ele alan yazar, teorinin açıklamalarıyla Çeçen kadınların eylemlerinin çeliştiğini ve bunda da sosyolojik etkenlerin önemli bir yeri olduğunu belirtmektedir. ${ }^{22}$

\footnotetext{
${ }^{18}$ Vamık Volkan, "İntihar Bombacıları”, Akademik ORTA DOĞU, 2010, Cilt 4, Sayı 2, s. 3.

${ }^{19}$ Murat Yahşi, Terör Örgütlerinde İntihar Bombacısı Kişiliği ve Etkinliğii, Yüksek Lisans Tezi, Kara Harp Okulu Komutanlığı Savunma Bilimleri Enstitüsü, 2015, s. 10.

${ }^{20}$ Anne Speckhard and Khapta Akhmedova, "Black Widows and Beyond: Understanding the Motivations and Life Trajectories of Chechen Female Suicide Terrorists", in Cindy Ness (Ed.) Women Terrorists and Militants: Agency, Utility and Organization, 2007, s. 110.

${ }^{21}$ Francine Banner, "Mothers, Bombers, Beauty Queens, Chechen Women's Roles in the Russo-Chechen Conflict", Georgetown Journal of International Affairs, Cilt 9, Sayl 2, s. 80.

${ }^{22}$ Çiğdem Aydın Koyuncu, "Chechen Female Suicide Bombers Within the Framework of Feminist International Relations Approach: An Analysis on the Basis of Contradictions",
}

\section{9}

Güvenlik Stratejileri

Cilt: 15

Sayı: 30 


\section{Halit GÜLŞEN}

360

Güvenlik Stratejileri

Cilt: 15

Sayı: 30

Çeçen kadın intihar eylemcilerinin yakınlarıla yapılan mülakatlarda, eylemlere destek verildiğini görmek mümkündür. $\mathrm{Bu}$ desteğin arkasında yatan sebepler olarak da temelde kendilerine yapılan uygulanan baskı politikaları, çocuklarının kaçırılmaları ve bir şekilde dünyaya seslerini duyurmak istemeleri ve intikam duygusu ön plana çıkmaktadır.

Çeçen intihar eylemleri üzerinde duran diğer yazarlar, Kurz ve Bartles'dir. Çeçenistan'daki intihar saldırılarını Afganistan'daki saldırılarla karşılaştıran yazarlar, Çeçen intihar eylemlerinin arkasında umutsuzluk, milliyetçilik ve köktenciliğin olduğunu kaydetmektedir. ${ }^{23}$ Moore, Çeçenistan ve Kuzey Kafkasya bölgesinde düzenlenen intihar saldırılarını incelemiş ve dinî radikalleşmenin, bağımsızlık duygusunun, milliyetçiliğin Çeçenler üzerindeki etkisine vurgu yapmıştır. ${ }^{24}$ Alanyalı da benzer tespitte bulunarak Çeçenistan'daki radikalleşme sürecinin monolitik olmadığını, bağımsızlık için sosyal hareketleri kapsayan bir ulusal direnişten başladığını ancak zaman içinde İslami radikalizm ve terörizme kaydığına dikkat çekmektedir. ${ }^{25}$

Dobayev, Kuzey Kafkasya'daki terör eylemlerini incelediği çalışmasında, Çeçenlerin Birinci Çeçen Savaşı'nda bu yönteme başvurmadıklarını ancak 2000'li yılların ardından intihar saldırısı yöntemini ağırlıklı olarak kullanmaya başladıklarını kaydetmiştir. ${ }^{26}$ Yazar, bu yükselişe gerekçe olarak bölgede artan dinî radikalizm ve Vahabizm'i göstermiştir. Çudinov da Çeçen intihar eylemlerinin yükselişinde dinî ve milliyetçi duyguların yanı sıra, sınırlı askerî envanterin de etkili olduğunu, bu nedenle de intihar eyleminin en

Alternative Politics, 2011, Vol. 3, No. 2, s. 180.

${ }^{23}$ Robert W. Kurz, Charles K. Bartles, "Chechen Suicide Bombers", Journal of Slavic Military Studies, 2007, Sayı 20, s. 531.

${ }^{24}$ Cerwyn Moore, "Suicide Bombing: Chechnya, the North Caucasus and Martyrdom", Europe-Asia Studies, 2012, s. 1783.

${ }^{25}$ Ali Alp Alanyalı, The radicalızation in chechnya From natıonalıst insurgency to Islamic terrorısm, Yüksek Lisans Tezi, Koç Üniversitesi Sosyal Bilimler Enstitüsü, 2014, s. 4.

${ }^{26}$ İgor Prakopeviç Dabayev, Sovremennıy terrorizm na Severnom Kavkaze, Prablemı Natsionalnoy Strategii, 2009, Sayı 1, s. 79. 
İntihar Saldırıları Üzerine Bir İnceleme: Çeçen İntihar Eylemleri

masrafsız ve doğrudan hedefe odaklanan bir yöntem olması sebebiyle kullanıldığını belirtmektedir. ${ }^{27}$ Matişov ve Paşçenko da Rusya'da yaşanan Çeçen soruna yönelik çalışmalarında bölgeye dışarıdan gelen Vahabizm etkisine vurgu yapmıştır. ${ }^{28}$ Buna gerekçe olarak, Sufi geleneği temsil eden din adamlarına yönelik düzenlenen intihar saldırıları gösterilmekte ve bu noktadaki dinî motivasyona dikkat çekilmektedir.

\section{2. Şiddete Varan Radikalleşme ve İntihar Saldırıları}

$\mathrm{Bu}$ çerçevede bir değerlendirme yaptığımızda gerek intihar saldırıları, gerekse Çeçen intihar saldırıları noktasında şiddete varan radikalleşme olgusunun önemli yer tuttuğu görülmektedir.

Bireyin radikalleşme süreci; kişinin kendisinden başlayan ve sırasıyla ailesi, akrabaları, arkadaş çevresi, okul arkadaşları, sosyal çevre (dernekler, gruplar vb.) ve dişsal unsurlar gibi içten dışa doğru genişleyen bir alanı kapsar. ${ }^{29}$ Terörizm literatüründe ise radikalleşme, genellikle "teröre giden yolda uygun motivasyonel ve algısal ön şartların oluşmasını sağlayan" süreçleri tanımlamak için kullanılan bir kavram olarak yer almaktadır. ${ }^{30}$

Örneğin Gurr, radikalleşmeyi, "bir grubun sosyal ya da siyasal bir amaç için mobilize olduğu fakat bunda başarısız olup bazı aktivistleri tatmin edememesini içeren bir süreç" olarak ifade ederken; Sprinzak'a göre radikalleşme, terörizmle sonuçlanan fakat belli bazı yöneticilere ya da sosyal politikalara karşıtlıkla başlayıp, sistemden umudun kesilmesi ve bu sistemin külliyen değiştirilmesi gerektiği düşüncesinden beslenen bir süreç olarak anlaşılabilmektedir. ${ }^{31}$ Yılmaz, radikalleşmeyi terörle

27 Сергей Иванович Чудинов, Терроризм смертников Проблемь научнофилософского осмысления, Флинта, 2010, s. 8.

${ }_{28}$ Gennadiy Prigareviç Matişov, İrina Vladimirovna Paşçenko, "Terrorizm kak glavnaya ugroza natsionalnoy bezapasnosti na Yuge Rassii”, SKGS, 2011, s. 26.

${ }^{29}$ Oktay Çelik, "Dini İstismar Eden Terör Örgütlerinde Radikalleşme Süreçleri”, Süleyman Demirel Üniversitesi Sosyal Bilimler Enstitüsü Dergisi, 2015, Sayı:22, s. 105.

30 David Mandel, "Radicalization: What does it mean", Thomas M., Pick, Anne Speckhard and Beatrice Jacuch (ed), Homegrown Terrorism, 2009, IOS Press, s. 107.

${ }^{31}$ Ted R. Gurr, Why Men Rebel, Princeton University Press, Princeton NJ, 1970, s. 17.; 


\section{Halit GÜLŞEN}

362

Güvenlik Stratejileri

Cilt: 15

Sayı: 30

sonuçlanan bir sürecin safhalarından biri olarak görmektedir. Ona göre, şiddetin benimsenmesi yoluyla terörle sonuçlanan bu süreci anlamak için beş safha üzerine yoğunlaşmak faydalı olacaktır. Bu safhalar, çocukluk çağındaki tecrübeler, ilköğretim çağlarında yaşanan tecrübeler, siyasal sosyalleşme, radikalleşme ve şiddetin benimsemesi safhalarıdır. ${ }^{32}$

Radikalleşme genel olarak, bazen şiddet içeren aşırı uç eylemlerle ve terör eylemleriyle sonuçlanan bir süreç olarak görülmektedir. Diğer bir ifadeyle, "terör eylemleriyle sonuçlanabilecek görüş, düşünce ve fikirleri kucaklayan insanların oluşturduğu bir olgu" olarak tanımlamaktadır. ${ }^{33}$ Bu bakımdan, radikalleşme sabit aşamalardan geçip sabit hızla ilerleyen doğrusal bir süreç olarak değil; yerel bağlama ve bireysel unsurlara bağl1 değişken bir süreç olarak görülmektedir. Radikalizm sosyal, siyasal düzende kökten bir değişim öngören ve değişim için yalnızca siyasal araçlara değil şiddete de başvurmayı meşru sayan grup davranışları için kullanılan bir terimdir. Radikal eylemi demokratik hak ve talepleri içeren herhangi bir eylemden ayıran en temel unsur, şiddetin bir yöntem olarak tercih edilmiş olmasıdır. ${ }^{34}$

İntihar saldırısı olgusunun bir bakıma şiddete varan radikalleşme sonucunda ortaya çıkan bir durum olduğunu belirtmek yanlış olmaz. İntihar saldırganı olarak ele alınan bir kişinin, belli sebeplerden dolayı hem kendi hayatına, hem de çoğu kez hedef gözetmeksizin başkalarının hayatına kastettiği dikkate alındığında, bir şiddete varan radikalleşme süreci yaşamış olması beklenir. Bu süreç bazılarında çok kısa olabileceği gibi, bazılarında daha uzun bir zaman alabilmektedir. Ancak sonuçta her şiddete varan radikalleşme sürecine tâbi olan bireyin intihar eylemcisi

Ehud Sprinzak, "Violence and catastrophe in the theology of Rabbi Meir Kahane: The ideologization of mimetic desire", Terrorism and Political Violence, 1991, Cilt 3, Say1 3 , s. 55 .

${ }^{32}$ Kamil Y1lmaz, Disengagement from terrorism: Lessons from the Turkish Penitents, 2014, New York: Routledge, s. 143.

$33 \mathrm{http} / / /$ ec.europe.eu/dgs/homeaffairs/what-we-do/policies/crisis-and-terrorism/radicalisa tion/index_en_htm.

${ }^{34}$ Hilmi Demir, Radikal Selefi Hareketler ve Terör Örgütleri: Kavram ve Teorik Çerçeve, Türkiye Ekonomi Politikaları Araştırmaları Vakfi, Değerlendirme Notu, Ankara, 2016, s. 5. 
İntihar Saldırıları Üzerine Bir İnceleme: Çeçen İntihar Eylemleri

olmayacağı ancak her intihar eylemcisinin şiddete varan radikalleşmeye tâbi olduğu muhakkaktır.

Radikalleşmeyi hem devlet, hem de devletdışı aktörlerin çatışmaya hazırlanma pratikleri şeklinde kavramsallaştırmak suretiyle ele alan McCauley ve Moskalenko, bir devletin ve bu devletin vatandaşlarının çatışma ya da savaşa giden yolda giderek artan şekilde radikalleşerek, bunu maruz kaldıkları terörist saldırılara bir cevap olarak benimseyebileceklerini kaydetmektedir. ${ }^{35}$ McClauley ve Moskalenko, radikalleşme süreçlerinde sosyal grupların etkisine de dikkati çekmektedir. Buna göre, radikalleşen farklı bireyler bir araya gelerek şöyle bir grup düşüncesine bürünür: "Biz seçilmiş ve özel kişileriz. Bize kimse adil davranmadı, haklarımızla ilgilenmedi ve yardım etmedi." ${ }^{36}$

McClauley ve Moskalenko'nun bireyleri radikal örgütlere iten faktörlere dair yaptığı şu sınıflandırmanın da konu açısından dikkate değerdir: Siyasi nedenler, kişisel nedenler, çözülme, kaçış, statü ve macera isteği "Sifir hayattan kahramanlığa (from zero to hero)" olarak özetlenebilecek bu kategoride bazıları çok da ideolojiye takılmadan sırf macera ve heyecan için radikalleşerek terör örgütlerine katılmakta ya da örgütlerden bağımsız olarak intihar saldırılarında bulunmaktadır. ${ }^{37}$

\section{Din Adamlarına Yönelik Saldırılar}

Rusya'nın Kuzey Kafkasya cumhuriyetlerinde son dönemde din adamlarına karşı yapılan suikastlerde artış görülmektedir. Aşağı daki tarihlere ve tabloya baktığımızda durum daha net anlaşılacaktır: ${ }^{38}$

\footnotetext{
${ }^{35}$ Clark McCauley and Sophia Moskalenko, "Mechanisms of political radicalization: Pathways toward terrorism", Terrorism and Political Violence, 2008, Say1 20 (3): 425. 11 Eylül saldırısı bu duruma örnek olarak gösterilebilir.

${ }^{36}$ Clark McCauley, Sophia Moskalenko, Friction: How Radicalization Happens to Them and Us, Oxford University Press, London, 2011, s. 35.

${ }_{37}^{37}$ McCauley ve Moskalenko, a.g.e., s. 428.

${ }^{38}$ Ubiystva islamskih deyateley na Cevernom Kavkaze, Kavkazskiy Uzel, 2016, http://www.kavkaz-uzel.eu/articles/244966/.
}

\section{3}

Güvenlik Stratejileri

Cilt: 15

Sayı: 30 


\section{Halit GÜLŞEN}

364

Güvenlik Stratejileri

Cilt: 15

Sayı: 30

6 Ocak 2001: Çeçenistan, Urus Martan'da Bölge İmamı Hasmagomed Umalat

9 Ocak 2001: $\quad$ Çeçenistan, Gremençuk Köyü, Cami İmamı Magomed Hasuyev

4 Mayıs 2001: Çeçenistan, Şalinskiy Bölgesi, Cami İmamı Hasruddin Matuyev

31 Ağustos 2003: Çeçenistan, Vedenskiy Bölgesi, Müftü Şaimana Madogoda

5 Ağustos 2006: Karaçay-Çerkes, İmam Abdülkerim Baynamukov

8 Ağustos 2006: Karaçay-Çerkes, Mana Ayagı Köyü, Efendilerden İsmail Batçayev

25 Eylül 2006: Karaçay-Çerkes ve Stavrapol Kray İmamı Ebubekir Kurciyev

22 Subat 2007: $\quad$ Dağıstan, Mahaçkale, Molla Dagir Kaçayev

21 Temmuz 2007: İnguşetya, Vaha Vedziyev, (araca bomba)

26 Temmuz 2007: Dağıstan, Mahaçkale, Müftü Yardımcısı Kurbanmagomed Ramazanov, (araca bomba)

30 Eylül 2007: $\quad$ Dağıstan, Karabudak Bölgesi, Dinî Alim (isim yok)

19 Nisan 2009: İnguşetya, Nazran, Molla Musa Esmurziyev

1 Mayıs 2009: $\quad$ İnguşetya, Sunjen, Said Hasan Saidibrahim

25 Mayıs 2009: Dağıstan, Mahaçkale, Müftü Yardımcısı Ahmet Tagayev

14 Temmuz 2009: İnguşetya Abdurrahman Kartayev

20 Eylül 2009: $\quad$ Karaçay-Çerkes, İslam Enstitüsü Rektörü, İsmail Bostanov

10 Ekim 2010: Tümeni, İmam İsamitdin Akbanov

1 Kasım 2010: $\quad$ Dağıstan, Hasavyurt, İmam Baris Salamgireyev

15 Aralık 2010: $\quad$ Kabardey-Balkar, Nalçik, Anas-hacı Pşihaçev

9 Nisan 2011: $\quad$ Dağıstan, Kızılyurt, İmam Magomed Saypudinov

10 Temmuz 2011: Dağıstan, Buynak, İmam Magomed Mahdiyev

14 Temmuz 2011: Dağıstan, İmam Aşurbek Kurbanov

3 Eylül 2011: $\quad$ İnguşetya, Mavladi Buzurtanova

15 Eylül 2011: Dağıstan, Buynak, İmam Zaynutin Dayziyev

27 Ekim 2011: $\quad$ Dağıstan, Şeyh Sinajuddin İsrafilov

13 Șubat 2012: $\quad$ Pyatigorsk, Stavropol-Kray Müftü Yardımcısı Kurman İsmailov

23 Mart 2012: $\quad$ Dağıstan, Buynask, İmam Gitino Magomed Abdulgaripov

28 Temmuz 2012: Dağıstan, Buynask, İmam Magomedkamilya Gamzatova

19 Temmuz 2012: Tataristan, Kazan, Müftü İldus Faizov

30 Ağustos 2012: Dağistan, Şeyh Said Efendi. 
Tablo 1: Rusya'da Din Adamlarına Yönelik Saldırılar.

\begin{tabular}{|c|c|c|c|c|c|c|c|c|c|c|c|c|c|}
\hline & $\overline{\mathrm{\delta}}$ & 용 & ڤి & 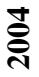 & ஜ̊ & §ి & 횽 & ஜ̊ఃి & 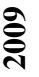 & $\stackrel{\ominus}{\vec{\ominus}}$ & $\overline{\bar{\delta}}$ & 귱 & $\stackrel{0}{0}$ \\
\hline Dağıss. & - & - & - & - & - & - & 3 & - & 1 & 1 & 5 & 3 & 13 \\
\hline İnguş. & - & - & - & - & - & - & 1 & - & 3 & - & 1 & - & 5 \\
\hline Karaç. & - & - & - & - & - & 3 & - & - & 1 & - & - & - & 4 \\
\hline Kabar. & - & - & - & - & - & - & - & - & - & 1 & - & - & 1 \\
\hline Çeçen. & 3 & - & 1 & - & - & - & - & - & - & - & - & - & 4 \\
\hline Tatar. & - & - & - & - & - & - & - & - & - & - & - & 1 & 1 \\
\hline Stav. & - & - & - & - & - & - & - & - & - & - & - & 1 & 1 \\
\hline TOP. & 3 & - & 1 & - & - & 3 & 4 & - & 5 & 2 & 6 & 5 & 29 \\
\hline
\end{tabular}

\section{5}

Güvenlik Stratejileri

Cilt: 15

Say1: 30

Tabloyu değerlendirdiğimizde

- 2007'nin bir dönemeç olarak alınmasıs gerekmektedir; çünkü Çeçen-İçkerya bu dönemde feshedilmiș ve "Kafkasya Emirliği" Umarov tarafindan ilan edilmişyi. 2001-2007 arası dönemde yedi din adamına saldırı düzenlenirken, 2007-2012'nin ortasını kapsayan dönemler arasında 22 saldırı yapıldığı görülmektedir. 2007'den sonra din adamlarına saldırılarda ciddi bir artış olduğu söylenebilmektedir.

- 2004-2012 arasında Çeçenistan'da bu tür bir saldırı olmadığı görülmektedir.

- 2012'de din adamlarına yönelik saldırıların Tataristan ve Stavrapol-Kray'a da sıçradığı fark edilmektedir. Bu durum "Emirliğin" faaliyet alanını genişletmeye çalıştı̆̆ının bir işaretidir.

- Diğer bir nokta, son 1,5 yilda Dağıstan'da sekiz din adamının öldürülmüş olmasıdır. Bu, direnişçilerin güç ve eylem merkezinin Çeçenistan'dan Dağıstan'a kaydığı tezini doğrulamaktadır.

- Yine son 1,5 y1lda 11 din adamına saldırı düzenlendiğini görülmektedir. $\mathrm{Bu}$ rakam da "Emirliğin" eylemlerinde bu yönde bir yaklaşım tarzını da benimsediğini, bundan sonra da bu hareket tarzının büyük oranda sürdürüleceğini göstermektedir. 


\section{Halit GÜLŞEN}

366

Güvenlik Stratejileri

Cilt: 15

Sayı: 30

Burada eylemlerin hepsi gerçekten "Emirliğin" içindeki Vahhabi-Selefi gruplar tarafindan mı yapıldığı sorusu sorulabilir.

Vahabi-Selefi akımın Kafkas direnişinde giderek etkin bir rol oynamaya başladığı açıktır. Elbette bu gruplar tek ve homojen bir yapıya sahip değildir. Rusya'nın milliyetçi Çeçen direnişini kırmak için bazı Vahabi grupları yönlendirdiği, bu vesileyle direnişte bölünmeye yol açmaya çalıştığı; ya da Rus politolog Aleksandr Dugin'in ifadeleriyle, “ABD'nin El-Kaide'si var, bizim de olmalı" düşüncesinden hareketle, bölgede tabiri caizse, canlı bomba eylemleri yapan, din adamlarını öldüren bir "öcü" yaratarak bölgede istediği her türlü askerî hareket tarzını yapmayı amaçlaması ve Batı' ya da "Bakın biz burada radikal İslam'la mücadele ediyoruz" tezini savunmak için argüman elde etmeye çalışması da açıkça görülmektedir.

Nedeni ister Rusya'nın taktiği, ister "Emirliğin" kendi inisiyatifi olsun, şu an ortaya çıkan tabloda Tataristan, Kabardey-Balkar, KarçayÇerkes, İnguşetya, Çeçenistan, Dağıstan'da çatışmalar ve operasyonlar yaşanmaktadır. Bu da, Çeçen savaşının kısmen kimlik değiştirerek "Tüm Kuzey Kafkasya'da bağımsız ve birleşik İslam devleti" kurulması amaçlandığ1 için eylemlerin Tataristan, Kabardey-Balkar, İnguşetya, Çeçenistan, Dağıstan gibi geniş bir alana yayılmasına neden olmuştur.

\section{4. Çeçen İntihar Eylemleri}

İntihar saldırılarının altında yatan nedenlerden biri olarak psikolojik faktörleri gösteren Sarraj, ailesinin ya da sevdiklerinden birinin gözünün önünde şiddete maruz kalan gençlerin, ileriki dönemde daha fazla şiddete eğilim gösteren bir ruhaniyete büründügünü kaydetmektedir. Sarraj, ayrıca şiddet görmenin ileri dönemlerde şiddet göstermek için bir motivasyona neden olduğunu vurgulamaktadır. ${ }^{39}$ Sarraj ve Açıkgöz'ün tespitleri Çeçen intihar saldırılarının motivasyonlarının

${ }^{39}$ Eyad El Sarraj and Linda Butler, "Suicide Bombers: Dignity, Despair, and the Need for Hope: An Interview with Eyad El Sarraj," Journal of Palestine Studies, 2002, Cilt 31, Sayı 4, s. 73. 
İntihar Saldırıları Üzerine Bir İnceleme: Çeçen İntihar Eylemleri

açıklanmasında son derece yararlıdır. Bu noktada ilk olarak "kara dullar" olarak adlandırılan, eşlerini, kardeşlerini ya da babalarını RusÇeçen savaşlarında kaybetmiş kadınların intihar eylemlerine yönelme nedenlerine bakmak faydalı olacaktır.

Yaşları 20'yle 30 arasında değişen "kara dullar", 2000'lerde intihar saldırılarına başlamıştır. Bu dönem aynı zamanda ilk Çeçen intihar saldırılarının da başladığı dönemdir. Söz konusu tarih Rusya-Çeçenistan arasındaki İkinci Çeçen Savaşı'nın hemen sonrasına denk gelmesi açısından önemlidir. "Kara Dullar" üzerine çalışması bulunan Aleksandra Cavelius, bu profile yönelik şöyle bir tanımlama getirmektedir:

"Kara dul olarak anılan bu kadın militanlar, Çeçenistan'da çocukluklarından beri yağma, işkence ve tecavüz olaylarlyla yan yana yaşamışlar. Çoğunun erkek kardeşi, oğlu, babası ya da kocası Rus askerleri tarafindan kaçırılmış, eziyet görmüş, katledilmiş. Onları bu şiddet ortamına sürükleyen nedenler, ideolojik olmaktan öte çaresizlikten kaynaklaniyor..."

Çeçen kadınların ikonası, adına şarkılar bestelenmiş, şiirler yazılmış olan 22 yaşındaki Havva Barayeva, 2000 yılı Haziran ayında Alkan Kala şehrinde bomba yüklü bir kamyonla 27 Rus askerini öldürmüştür. 2003 yılı Mayıs ayında İlaşhan-Yurt yerleşiminde 18 kişinin ölümüne, 145 kişinin yaralanmasına neden olan Şehide Baymuradova'nın 36 kadından oluşan bir hücrenin üyesi olduğu açıklanmıştır. Yine 2003 yılının Temmuz ayında Moskova'daki Krylya (Kanatlar) gençlik festivaline bir intihar saldırısı düzenleyen iki Çeçen kadını ise 16 kişinin ölümüne neden olmuştur. ${ }^{41}$

"Kara Dullar"ın intihar saldırılarındaki temel motivasyonlarına bakıldığında, intikam duygusunun ön plana çıktığı görülmektedir. Ancak bununla beraber söz konusu eylemi gerçekleştirdiklerinde Allah

\footnotetext{
${ }^{40}$ Christiane Hoffmann, Çeçenistan'da Kara Dullar, Deutsche Welle, 06.09.2004; http://www.dw.com/tr/\%C3\%A7e\%C3\%A7enistanda-kara-dullar/a-2526067.

${ }^{41}$ Anne Nivat The Black Widows: Chechen Women Join the Fight for Independenceand Allah, Studies in Conflict \& Terrorism, 2005, s. 418.
}

\section{7}

Güvenlik Stratejileri

Cilt: 15

Say1: 30 

yerleşmiş olan inanç, "Kara Dullar"a intihar saldırılarını gerçekleştirebilmeleri için adeta bir ruhsat vazifesi görmüştür.

Sayı: 30

Rusya topraklarında, özellikle de Çeçenistan başta olmak üzere Kuzey Kafkasya coğrafyasında "Kara Dullar" ile başlayan intihar saldırıları, devam eden süreçte ciddi artış göstermiş ve Çeçenlerin Rusya'ya karşı olan savaşında en önemli saldırı yöntemlerinden biri olma konumuna gelmiştir. Aşağıdaki tabloda, 2000-2016 zaman dilimi aralığında Rusya'da Çeçenler tarafindan düzenlenen ve tespit edebildiğimiz intihar saldırıları yer almaktadır.

Tablo 2: 2000-2016 Rusya'da Gerçekleştirilen İntihar Saldırıları. ${ }^{42}$

\begin{tabular}{|c|c|c|}
\hline Yıl & Ülke/Şehir & Saldırı Sayısı \\
\hline 2000 & Çeçenistan & 6 \\
\hline 2002 & Moskova & 1 \\
\hline 2003 & Çeçenistan-Stavropol & 3 \\
\hline 2004 & Moskova-Beslan & 3 \\
\hline 2009 & Çeçenistan & 1 \\
\hline 2010 & Moskova & 2 \\
\hline 2011 & Moskova-İnguşetya & 6 \\
\hline 2013 & Dağıstan & 2 \\
\hline 2014 & Moskova & 1 \\
\hline 2016 & Moskova-Stavropol-Çeçenistan & 4 \\
\hline
\end{tabular}

Tablo 2'de görüleceği üzere, Rusya'da 2000 yılına kadar Çeçenler tarafindan intihar saldırıları gerçekleştirilmezken, son 16 yılda 29 intihar saldırısının gerçekleştirildiği görülmektedir. Bu saldırılar ilk yıllarda sadece güvenlik güçlerini hedef alırken, ilerleyen dönemlerde saldırılarda sivillerin de hedef alındığı görülmektedir.

Bu noktada özellikle 2004'teki Beslan saldırısı dönüm noktas1 olarak kabul edilmektedir. Bu saldırıda Kuzey Osetya'daki Beslan kasabasında bir okul 30 kadar Çeçen tarafından işgal edilerek ve 18

${ }^{42}$ Speckhard, Akhmedova, a.g.e., s. 115. 
İntihar Saldırıları Üzerine Bir İnceleme: Çeçen İntihar Eylemleri

yaşın altında 1000 kadar çocuk rehin alınmış ve okulun her yerine patlayıcılar yerleştirilerek kuşatma iki gün sürdürülmüştür. Okulda kurtarma operasyonu yapmak için hazırlıklar sürerken aniden çatışmaların başlaması üzerine 331 rehine, 11 Rus askeri ve 31 Çeçen savaşçı ölmüştür. Beslan olayı, Çeçen militanların yaptığı en büyük hata olarak görülmektedir. Bu olaydan sonra Çeçen davasına her şeye rağmen sempati duyanların duygularında onarılamaz bir değişiklik görülmüş, Çeçen direnişçiler için daha çok insan "terörist" sıfatını kullanmaya başlamıştır.

\section{5. Çeçenleri İntihar Saldırılarına İten Nedenler}

Çeçenlerin İkinci Rus-Çeçen Savaşı'nın sona ermesinden itibaren intihar saldırılarına başvurmaya başlamalarının üzerine çok sayıda çalışma yapılmıştır. Bu çalışmalarda Çeçenlerin intihar saldırılarına başvurmalarının temel nedenleri olarak milliyetçilik, radikalleşme, rejim baskısı, intikam duygusu, dinî fanatizm, silah yetersizliği, propaganda gücü gibi nedenler ön plana çıkartılmıştır. ${ }^{43}$ Konuya dair Birinci Çeçen Savaşı ve İkinci Çeçen Savaşı'nın ardından ülkelerinden göç ederek Türkiye'ye yerleşen ve hâlen Türkiye'de bulunan, yaşları 13 ile 42 arasında değişen 14 Çeçen ile yaptığımız mülakatlar Çeçenleri intihar saldırısına sevk eden temel sebepler konusunda kayda değer bulgular sağlamaktadır.

Mülakat yapılacak Çeçenlerin tespiti sırasında ya kendilerinin ya da yakın ailelerinden insanların Çeçenistan'daki savaşlara ya da direniş eylemlerine katılmış olmalarına dikkat edilmiştir. Konunun hassasiyeti ve güvenlik kaygısı nedeni ile mülakatın muhataplarına herhangi bir

\footnotetext{
43 Aslında 2000-2016 arasında düzenlenen intihar saldırılarını iki evreye ayırmak daha yararlı olacaktır. Çünkü 2007'de Çeçen-İçerya Cumhuriyeti'nin Doku Umarov tarafindan feshedilerek Kafkasya Emirliği'nin ilan edilmesi ile birlikte, Çeçen direnişinin kimliği de değişmiştir. Bu tarihten itibaren sadece Çeçenistan'ın bağımsızlığı değil, tüm Kuzey Kafkasya'da bağımsız İslam devletinin kurulması esas amaç olarak belirlenmiştir. Ancak bu ayırım başka bir çalışmanın konusu olabilecek kadar uzun bir konu başlığı içerdiğinden, burada değinilmemiştir.
}

\section{9}

Güvenlik Stratejileri

Cilt: 15

Say1: 30 
370

Güvenlik

Stratejileri

Cilt: 15

Sayı: 30

imzalı belge doldurulmamış, ses kayd1, fotoğraf ya da görüntü alınmamıştır. Bu noktada şahısların kişisel bilgileri de bizde saklı kalarak, sadece yaşları verilecektir. Mülakat yapılan kişiler "örnek 1", örnek 2" kodlamasıyla verilmiştir. Katılımcılara "Çeçenistan'da insanların neden intihar saldırısı eylemlerine başvurduğu" sorusu yöneltilmiştir. Katılımcılara diğer vakalardan hareketle herhangi bir örnek neden sunulmamış, cevaplar tamamen kendilerine bırakılmıştır.

Konunun daha ayrıntılı değerlendirmesine geçmeden önce aşağıdaki tablonun incelenmesinde fayda görülmektedir.

Tablo 3: Çeçenleri İntihar Saldırısı Düzenlemeye İten Nedenler.

\begin{tabular}{|c|c|c|c|c|}
\hline & Yaş & Birinci Neden & İkinci Neden & Üçüncü Neden \\
\hline Örnek 1 & 30 & Esir düşmemek & İntikam & $\begin{array}{c}\text { Güç ve silah } \\
\text { yetersizliği }\end{array}$ \\
\hline Örnek 2 & 42 & İntikam & $\begin{array}{c}\text { Silah } \\
\text { yetersizliği }\end{array}$ & \\
\hline Örnek 3 & 40 & İntikam & & \\
\hline Örnek 4 & 29 & $\begin{array}{c}\text { Eylem etkisinin } \\
\text { fazlalı̆̆ }\end{array}$ & İntikam & $\begin{array}{c}\text { Yüksek zarar } \\
\text { verme isteği }\end{array}$ \\
\hline Örnek 5 & 23 & İntikam & & \\
\hline Örnek 6 & 13 & İntikam & & \\
\hline Örnek 7 & 32 & Silah yetersizliği & & \\
\hline Örnek 8 & 38 & Rejim baskıs1 & & Rejim baskıs1 \\
\hline Örnek 9 & 41 & Silah yetersizliği & Propaganda & \\
\hline Örnek 10 & 36 & İntikam & Rejim baskıs1 & \\
\hline Örnek 11 & 29 & Propaganda & $\begin{array}{c}\text { Silah } \\
\text { Ietersizliği }\end{array}$ & İntikam \\
\hline Örnek 12 & 27 & İntikam & & \\
\hline Örnek 13 & 32 & İntikam & & \\
\hline Örnek 14 & 32 & Silah yetersizliği & Propaganda & \\
\hline
\end{tabular}

Tablo 2'de görüldüğü üzere yapılan mülakatlarda Çeçenleri intihar saldırısında bulunmaya iten nedenler olarak şu cevaplar alınmıştır: İntikam almak, intihar saldırılarının eylem etkisinin fazlalığı (geniş kitlelere kısa sürede ulaşması ve etkilemesi), silah yetersizliği, propaganda etkisi, rejim baskısı, esir düşmemek ve yüksek zarar verme isteği. 
İntihar Saldırıları Üzerine Bir İnceleme: Çeçen İntihar Eylemleri

Katılımcılardan yedisi, yani \%50'si Çeçenleri intihar saldırısında bulunmaya iten birinci neden olarak intikam alma isteğini göstermiştir. İkinci ve üçüncü nedenlerdeki intikam alma cevapları da bu kapsamda birlikte değerlendirildiğinde, 14 kişiden 10 'unun intikam alma yönünde bir görüş belirttiğini söylemek yanlış olmaz.

İntikam alma isteğinin ardından gelen ikinci sebep ise silah eksikliği olarak göze çarpmaktadır. Üç katılımcı birinci neden olarak Çeçen savaşçıların ellerindeki silahların yetersiz olduğunu, bundan dolayı intihar saldırılarına yönelmek zorunda kaldıklarını belirtmiştir. Yine bu başlıkta da iki kişi, ikinci neden olarak silah yetersizliğini işaret etmiş, bir kişi ise üçüncü neden olarak silah yetersizliğini göstermiştir. Diğer cevaplarda ise biri kişinin esir düşmemek, rejim baskısı ve propaganda etkisini birinci neden olarak öne sürdüğü görülmektedir.

Elde ettiğimiz veriler, özellikle son dönemde literatürde yer alan yayınların aksine, dinî fanatizmin ya da radikal köktenciliğin Rusya'daki intihar saldırıların temel motivasyon kaynağı olmadığını, hatta ilk üç neden sıralaması içine bile giremediğini göstermektedir. Elbette ortaya çıkan bu tablo, dinî radikalizmin bu vakalarda etkisi olmadığı olarak yorumlanamaz. Çünkü bu saha araştırması 14 kişi ile yapılan sınırlı bir kapsama sahiptir. Ancak yine de katılımcılardan hiçbirinin din ya da cihat vurgusu yapmamış olması kayda değerdir.

$\mathrm{Bu}$ tespitlerin dışında mülakatlar sırasında öne çıkan bazı noktalar üzerinde durmakta yarar görülmektedir. 13 yaşında olan "Örnek 6"nın sorumuza verdiği cevapta birinci neden olarak intikam alma isteğini göstermesi son derece önemlidir, çünkü ailesinde kayılar yaşamış olan, işkence ve kötü muameleye maruz kalmış kişiler bulunan "Örnek 6", intihar saldırısını haklı bir gerekçe olarak görmektedir.

Çeçenistan'da bir dönem savaşçılar arasında yer almış olan "Örnek 1"in de mülakat sırasında kullandığg bir ifade dikkat çekici bulunmuştur. "Örnek 1" düşmana zarar vererek ölmenin, Allah katında intihar olarak değerlendirileceğine inanmadığını kaydetmiştir. Bu ifade dinin şahsi yorumlanmasının nasıl sonuçlar doğurabileceğine dair önemli örnek teşkil etmektedir. 


\section{Halit GÜLŞEN}

372

Güvenlik Stratejileri

Cilt: 15

Sayı: 30

"Örnek 12"nin, "Çeçenistan yönetimi tarafindan kendilerine yapılan zulmü ve baskıyı Ruslardan görmediklerini” söylemesi de mülakatlar sirasında elde edilen önemli bir bulgudur.

Mülakat yapılan hemen hemen tüm Çeçenlerin ortak olarak belirttikleri şu nokta ise, kişisel yaşanmışlıkların insanları nasıl radikalize ettiğine dair çok önemli bir veri olarak kabul edilebilir:

“Bizim gözümüzün önünde evlerimizi yaktılar, kadınlarımıza, kız kardeşlerimize saldırdılar, tecavüz ettiler. Bizler yakınlarımızın gözümüzün önünde ölmesini kaldırabiliriz ancak onlar gözümüzün önünde işkence edilmesini, tecavüz edilmesini asla kaldıramayız. Bu saldırllarda bulunmayı ne yapacaktık. Bizi 300 yıldır öldürüyorlar."

\section{Analiz}

Makalede çalışmamızın kavramsal çerçevesini ortaya koyarken, radikalleşme üzerinde durmuş ve insanları intihar saldırısında bulunmaya iten en önemli nedenler arasında bu faktörün yer aldığını belirtmeye çalışmıştık. Yaptığımız araştırmanın sonuçları göz önünde bulundurulduğunda, Çeçenleri intihar eylemcisi olmaya iten nedenlerin başında radikalleşmenin olduğu açıktır. Aldığımız cevaplardan yola çıkarak şu tespiti yapmamız mümkündür:

Çeçenler, gerek Rusya yönetimi altında, gerekse Çeçenistan' daki Ramazan Kadirov yönetimi altında büyük zulme maruz kalmış, rejim baskısını çok yoğun bir şekilde üzerlerinde hissetmiştir. Özellikle yakın aile fertlerine gözleri önünde işkence yapılması, evlerinin yakılması, tecavüzler; onurları ve milliyetçi duyguları ile bilinen Çeçenlerin hızlı bir şekilde radikalleşmesine ve bu radikalleşmenin sonucunda da yoğun bir intikam duygusunun ortaya çıkmasına yol açmıştır.

Elbette bölgedeki farklı unsurlar ya da literatürün önümüze koyduğu ekonomik, sosyal, psikolojik, dinî fanatizm, milliyetçilik gibi insanları intihar saldırganı olmaya iten nedenler Çeçen örneğinde göz ardı edilemez. Ancak aldığımız cevaplar tahlil edildiğinde radikalleşme faktörünün diğer tüm etkenleri bastırdığı görülmektedir. Nitekim daha önceki bölümlerde de bahsettiğimiz üzere, ailesinin ya da sevdiklerinden 
İntihar Saldırıları Üzerine Bir İnceleme: Çeçen İntihar Eylemleri

birinin gözünün önünde şiddete maruz kaldığııı gören gençlerin, ileriki dönemde daha fazla şiddete eğilim gösteren bir ruhaniyete büründüğünü, şiddet görmenin ileri dönemlerde şiddet göstermek için bir motivasyona neden olduğunun tespiti, Çeçen intihar saldırıları ile birebir örtüşmektedir. ${ }^{44}$

373

Güvenlik Stratejileri

Cilt: 15

Say1: 30

\section{Sonuç}

Bu makalede ulusal ve uluslararası güvenlik çalışmalarında önemli yeri olan intihar saldırıları, bu saldırıların nedenleri, literatürde konuya dair yapılan çalışmalar ve bir vaka çalışması olarak Rusya'da gerçekleştirilen Çeçen intihar saldırıları üzerinde durulmuş, daha önce kullanılmayan bu yöntemin neden son 16 yılda kullanılmaya başlandığ 1 sorusuna cevap aranmıştır.

$\mathrm{Bu}$ noktada ilk olarak intihar saldırılarının literatürdeki yeri üzerinde durulmuştur. İntihar saldırganları hakkında tek tip bir profil ortaya çıkarmak oldukça güç olmakla birlikte, literatürde bireyi intihar saldırılarına iten temel faktörler arasında kin, intikam duygusu, dinî fanatizm, ideolojik fanatizm, şiddete maruz kalma, ekonomik ve sosyolojik olarak alt gruplarda yer alma gibi nedenlerin başlica unsur olarak değerlendirildiği görülmektedir.

İkinci olarak ise intihar saldırıları şiddete varan radikalleşmenin bir sonucu olarak ele alınmıştır. Bireyi intihar saldırganı olmaya iten nedenler bir süreç sonucunda ortaya çıkmakta ve eyleme dönüşmektedir. $\mathrm{Bu}$ süreç bazılarında çok uzun olabileceği gibi bazılarında beklenenden daha kısa sürede tamamlanabilir. Ancak her durumda, bireyde yukarıda belirtilen nedenleri ortaya çıkartacak bir şiddete varan radikalleşmenin oluşması beklenmelidir. Ancak burada dikkat edilmesi gereken nokta, her şiddete varan radikalleşme sürecinden geçen kişinin intihar eylemcisi olmayacağ radikalleşmeden geçeceğidir.

\footnotetext{
${ }^{44}$ Sarraj and Linda, a.y.
} 


\section{Halit GÜLŞEN}

374

Güvenlik Stratejileri

Cilt: 15

Sayı: 30

Üçüncü aşamada ise yapılan saha çalışması sonrasında, Çeçenleri intihar saldırılarında bulunmaya sevk eden temel neden olarak radikalleşme olgusunun varlığ neticesinde temelde Çeçenlerin maruz kaldığ 1 zulüm, şiddet, işkence, tecavüz, rejim baskısı gibi etkenlerin bu insanları radikalleştirdiği, bu radikalleşmeye de bağlı olarak yoğun bir intikam duygusu ortaya çıkarttığı görülmüştür. İntikam alma duygusunun yanı sıra silah yetersizliği, daha çok zarar verme isteği, propaganda amac1, esir düşme korkusu ve rejim baskısının da Çeçenleri intihar saldırılarına iten motivasyon kaynakları arasında yer aldığı görülmüştür. Öyle ki ortaya çıkan bu intikam duygusu dinî kuralların dâhi insanların kendi içinde bulundukları aşırı radikalleşme durumu nedeni ile çok rahatlıkla değiştirilebileceğini göstermiştir.

Çalışmada ulaşılan sonuçların özellikle son dönemde konuya dair literatürde yer alan çalışmalara şu yönde bir katkı sunabileceği düşünülmektedir. Son dönem çalışmalarda ve özellikle de genel olarak intihar saldırılarında, özellikle de bu saldırıyı gerçekleştiren kişi Müslüman bir kimliğe sahip ise, ilk olarak dinî fanatizm ya da radikalizm, İslam'daki cihat anlayışı kavramlarına atıf yapılmaktadır. Hâlbuki bu çalışma göstermiştir ki, Müslüman kimlikleriyle bilinen ve dinî konularda son derece muhafazakâr olan Çeçenleri intihar saldırılarında bulunmaya iten asıl neden dinî radikalizm ya da cihat anlayıșı değil, Rusya ile yaşanan savaşlarda ve sonrasında karşı karşıya kaldıkları şiddet ve baskının intikam duygusunu tetiklemesidir. Ayrıca ortaya çıkan bu intikam duygusunun İslam dininin tartışmasız bir şekilde yasakladığı "kendi canına kıyma", "masum sivilleri öldürme" gibi hükümlerin göz ardı edilmesine neden olduğu da üzerinde durulması gereken önemli bir diğer noktadır.

\section{Summary}

Suicide attacks, which play a critical role in national and international security studies, the reasons for these attacks, studies conducted in this respect and the Chechen suicide attacks occurring in Russia as a casework have been addressed in this article; answers have 
İntihar Saldırıları Üzerine Bir İnceleme: Çeçen İntihar Eylemleri

been sought to the question of why this method that was not used before has started being used in the last 16 years.

First, at this point, the role of suicide attacks in literature has been addressed. Although it is quite difficult to form a single profile for suicide attackers, it could be seen that reasons like hatred, desire for vengeance, religious fanaticism, ideological fanaticism, being subjected to violence, and being present in sub-groups in economic and sociological terms are considered as the main factors in literature that push individuals to commit suicide attacks.

Second, suicide attacks have been addressed as a consequence of radicalism reaching the extent of violence. Reasons that push an individual to be a suicide attacker emerge as a consequence of a process and turns into an action. For some, this process could take a long time to be completed, while for others it could be completed in a shorter period than expected. Yet, in all circumstances, one must wait for radicalism that reaches the extent of violence to appear in an individual that could cause the above-mentioned reasons. The point to which attention must be paid here is that not everyone going through a radicalism process to the extent of violence becomes a suicide attacker; on the other hand, each suicide attacker will go through a radicalism process that reaches the extent of violence.

In the third part, following the field study conducted, the presence of radicalism, as the main reason for causing Chechen suicide attacks, has been identified. Based on the findings obtained, it has been found that factors such as persecution, violence, torture, rape, and regime pressure that Chechens are exposed to causes them to radicalize and this radicalization in effect creates an intensive desire for vengeance. Other than the desire for vengeance, it has also been found that lack of weapons, wanting to cause more harm, propaganda purposes, and fear of being captured as a prisoner and regime pressure are also among the sources of motivation that pushes the Chechens into committing suicide attacks. In fact, this desire for vengeance shows that the extreme radicalization that people find themselves in could even change and justify the acts strictly forbidden by religious rules. 


\section{Halit GÜLŞEN}

376

Güvenlik Stratejileri

Cilt: 15

Sayı: 30

It is believed that the results obtained from the study could contribute to other studies found recently in the literature on this issue in the following way. In the recent studies and particularly in incidents related to suicide attacks, if the person committing the attack is Muslim, references are made firstly to concepts of religious fanaticism or radicalism and jihad perception. However, this study has brought forth that the actual reason pushing the Chechens, known for being Muslim and religiously being extremely conservative, to commit suicide attacks is not religious radicalism or jihad, but their desire for vengeance being retriggered as a result of the violence and pressure that they have been faced with during and following the wars with Russia. Another important point that must be addressed is that this desire for vengeance causes provisions like "taking one's own life" and "killing innocent civilians" that have been strictly forbidden in Islam to be ignored.

\section{Kaynakça}

\section{Kitaplar}

ÇUDİNOV, S.İ., Terrorizm smertnikov (İntihar Terörizmi), Flinta, Nauka, 2010. BLOOM, Mia, Dying to Kill: The Allure of Suicide Terror, New York: Columbia. DOBAYEV, İ.P., Savremenniy terrorizm vı mire i na Severnom Kavkaze: suşçnost, praktika, opıt protiodeystviya (Dünyada ve Kuzey Kafkasya'da Çağdaş Terörizm), Orientir, 2010.

MATIŞOV, G.G., Paşçenko I.V., Terrorizm kak glavnaya ugroza natsionalnoy bezapasnosti na Yuge Rassii Rostov-na-Donu: İd-vo (Güney Rusya'da Ulusal Güvenlik Tehdidi Olarak Terörizm), SKAGS, 2011.

Türkiye ve Terörizm, Türkiye Barolar Birliği, Türkiye Barolar Birliği Yayınları, 2006.

\section{Makaleler}

AÇIKGÖZ, Reşat, “İntihar Saldırıları: Terör mü Özgürlük Arayışı mı?”, Akademik Incelemeler Dergisi, Cilt: 8, Say1: 2, Y11: 2013.

ATRAN, Scott, "Genesis of Suicide Terrorism", Science, 299, 2003.

AYDIN KOYUNCU, Çiğdem, "Chechen Female Suicide Bombers Within the Framework of Feminist International Relations Approach: An Analysis on the Basis of Contradictions", Alternative Politics, Vol. 3, No. 2, 179-197, September 2011.

AYDINALP, Halil, "İntihar Eylemlerinde Dinin Anlamı ve Sinırları", M.Ü. Ilahiyat Fakültesi Dergisi, 37 (2009/2), 129-146. 
İntihar Saldırıları Üzerine Bir İnceleme: Çeçen İntihar Eylemleri

BANNER, Francine, "Mothers, Bombers, Beauty Queens, Chechen Women's Roles in the Russo-Chechen Conflict", Culture\&Society, Summer/Fall 2008.

BLOOM, Mia M., "Palestinian Suicide Bombing: Public Support, Market Share, and Outbidding", Political Science Quarterly 119, no. 1 (Spring 2004), 61-88.

ÇELIK, Oktay, "Dini İstismar Eden Terör Örgütlerinde Radikalleşme Süreçleri”, Süleyman Demirel Üniversitesi Sosyal Bilimler Enstitüsü Dergisi, Y11: 2015/2, Say1:22.

HOFFMANN, Christiane, "Çeçenistan'da Kara Dullar", Deutsche Welle, 06.09.2004.

KALDOR, Mary, "In Defence of New Wars", Stability, 2013.

KARAOSMANOĞLU, Ali L., "Yirmibirinci Yüzyılda Savaşı Tartışmak: Clausewitz Yeniden”, Uluslararası İlişkiler, Cilt 8.

KUSHNER, Harvey W., "Suicide Bombers: Business as Usual", Studies in Conflict and Terrorism 19, no. 4 (1996), no. 120 (Sep.-Oct. 2000), 66-73.

KURZ, Robert W., Charles K. Bartles, "Chechen Suicide Bombers", Journal of Slavic Military Studies, 20: 529-547, 2007.

LIND, William, Keith Nightengale, John Schmitt, Joseph Sutton, Gary Wilson, "The Changing Face of War: Into the Fourth Generation", Marine Corps Gazette, 1989, s. 26.

MOORE, Cerwyn, "Suicide Bombing: Chechnya, the North Caucasus and Martyrdom", Europe-Asia Studies, 2012.

NIVAT, Anne, "The Black Widows: Chechen Women Join the Fight for Independence - and Allah", Studies in Conflict \& Terrorism, 2015.

SARRAJ, Eyad El and Linda Butler, "Suicide Bombers: Dignity, Despair, and the Need for Hope: An Interview with Eyad El Sarraj", Journal of Palestine Studies, 31, no. 4 (Summer 2002), 71-76.

SEVINÇ, Bilal, "İntihar Bombacıları ve Ölümün Rasyonelleştirilmesi”, Uluslararası Güvenlik ve Terörizm Dergisi, 2012, 3 (1): 67-86.

SPRINZAK, Ehud, "Rational Fanatics", Foreign Policy, 2000, Sayı 120.

VOLKAN, Vamık, "İntihar Bombacıları", Akademik ORTA DOĞU, Cilt 4, Sayı 2, 2010.

Tezler

AKDAŞ, Fatih, İntihar Terörizm ve Din, Yüksek Lisans Tezi, Kahramanmaraş Sütçü İmam Üniversitesi, Din Sosyolojisi Anabilim Dalı, 2009.

ALANYALI, Ali Alp, The radicalization in Chechnya from Nationalist İnsurgency to Islamic Terrorism, Yüksek Lisans Tezi, Koç Üniversitesi Sosyal Bilimler Enstitüsü, 2014.

AYDINALP, Halil, İntihar Eylemleri Ekseninde Din ve Terör İlişkisi, Doktora Tezi, Marmara Üniversitesi İlahiyat Fakültesi, 2008.

YAHŞİ, Murat, Terör Örgütlerinde İntihar Bombacısı Kişiliği ve Etkinliği, Yüksek Lisans Tezi, Kara Harp Okulu Komutanlığı Güvenlik Bilimleri Anabilim Dalı, 2015. 